\title{
Analysis of hematologic and serum chemistry values of Spheniscus magellanicus with molecular detection of avian malarial parasites (Plasmodium spp.) ${ }^{1}$
}

\author{
Sabrina D.E. Campos ${ }^{2 *}$, Jeferson R. Pires ${ }^{3}$, Cristiane L. Nascimento ${ }^{4}$, Gustavo \\ Dutra $^{4}$, Rodolpho A. Torres-Filho ${ }^{5}$, Helena K. Toma ${ }^{6}$, Beatriz Brener ${ }^{7}$ \\ and Nádia R.P. Almosny ${ }^{8}$
}

\begin{abstract}
Campos S.D.E., Pires J.R., Nascimento C.L., Dutra G., Torres-Filho R.A., Toma H.K., Brener B. \& Almosny N.R.P. 2014. Analysis of hematologic and serum chemistry values of Spheniscus magellanicus with molecular detection of avian malarial parasites (Plasmodium spp.). Pesquisa Veterinária Brasileira 34(12):1236-1242. Departamento de Patologia e Clínica Veterinária, Faculdade de Veterinária, Universidade Federal Fluminense, Rua Vital Brazil Filho 64, Vital Brazil, Niterói, RJ 21230-360, Brazil. E-mail: s.destri@gmail.com

Magellanic penguins (Spheniscus magellanicus) routinely migrate from their breeding colonies to Southern Brazil often contracting diseases during this migration, notably avian malaria, which has been already reported in Brazil and throughout the world. Detection of Plasmodium spp. in blood smears is the routine diagnostic method of avian malaria, however it has a low sensitivity rate when compared to molecular methods. Considering the negative impact of avian malaria on penguins, the aim of this study was to detect the presence of Plasmodium spp. in Magellanic penguins using Polymerase Chain Reaction (PCR) and by verifying clinical, hematological, and biochemical alterations in blood samples as well as to verify the likely prognosis in response to infection. Blood samples were obtained from 75 penguins to determine packed cell volume (PCV), red blood cell (RBC) and white blood cell (WBC) counts, mean corpuscular volume (MCV), uric acid, total protein, albumin, globulin and aspartate aminotransferase (AST) activity levels. Whole blood samples were used for PCR assays. Plasmodium spp. was detected in $32.0 \%$ of the specimens using PCR and in $29.3 \%$ using microscopic analyses. Anorexia, diarrhea and neurological disorders were more frequent in penguins with malaria and a significant weight difference between infected and non-infected penguins was detected. PCV and MCV rates showed no significant difference. RBC and WBC counts were lower in animals with avian malaria and leukopenia was present in some penguins. Basophil and lymphocyte counts were lower in infected penguins along with high monocyte counts. There was no significant difference in AST activities between infected and non-infected animals. There was a significant increase in uric acid values, however a decrease in albumin values was observed in infected penguins. Based on this study, we concluded that Plasmodium spp. occurs in Magellanic penguins of rehabilitation centers in Southeastern
\end{abstract}

\footnotetext{
${ }^{1}$ Received on March 31, 2014.

Accepted for publication on October 8, 2014.

${ }^{2}$ Doutoranda em Clínica e Reprodução Animal, Departamento de Patologia e Clínica Veterinária, Faculdade de Veterinária, Universidade Federal Fluminense (UFF), Rua Vital Brazil Filho 64, Vital Brazil, Niterói, RJ 21230360, Brazil. *Corresponding author: s.destri@gmail.com

${ }^{3}$ Docente da Universidade Estácio de Sá, Estr. Boca do Mato 850, Vargem Pequena, Rio de Janeiro, RJ 22783-325. E-mail: jefveterinario@yahoo.com.br

${ }^{4}$ Médico Veterinário do Aquário Municipal de Santos, Av. Bartolomeu de Gusmão s/n, Ponta da Praia, Santos, SP 11030-500, Brazil. E-mails: cristianelassalvia@hotmail.com, dutravet@ig.com.br
}

\footnotetext{
${ }^{5}$ Docente do Departamento de Zootecnia, Faculdade de Veterinária, UFF, Niterói, RJ.E-mail: ratf@vm.uff.br

${ }^{6}$ Docente do Departamento de Análises Clínicas e Toxicológicas, Faculdade de Farmácia, Universidade Federal do Rio de Janeiro (UFRJ), Cidade Universitária, Ilha do Fundão, Rio de Janeiro, RJ 21944-970, Brazil. E-mail: hktoma@globo.com

${ }^{7}$ Docente do Departamento de Microbiologia e Parasitologia, Instituto Biomédico, UFF, Rua Professor Ernani Melo 101, Centro, Niterói, RJ 24210-130. E-mail: brener@vm.uff.br

${ }^{8}$ Docente do Departamento de Patologia e Clínica Veterinária, Faculdade de Veterinária, UFF, Niterói, RJ. E-mail: almosny@vm.uff.br
} 
Brazil, compromising the weight of infected animals with clinical alterations appearing in severe cases of this disease. It was also noted that, although the hematological abnormalities presented by these animals may not have been conclusive, leukopenia, monocytosis and the decrease of basophils and lymphocytes revealed an unfavorable prognosis, and Plasmodium spp. infections may progress with elevated uric acid concentration and low albumin levels.

INDEX TERMS: Magellanic penguin, Spheniscus magellanicus, Plasmodium spp., avian malaria parsite, polymerase chain reaction, biochemistry, prognosis.

RESUMO.- [Análise dos valores hematológicos e bio-
químicos de Spheniscus magellanicus com detecção
molecular de parasitos maláricos aviários (Plasmo-
dium spp.).] O pinguim-de-Magalhães (Spheniscus madium spp.).] 0 pinguim-de-Magalhães (Spheniscus ma-
gellanicus) migra das suas colônias reprodutivas até o extremo sul do Brasil. Esses pinguins frequentemente são acometidos por doenças, notavelmente a malária aviária, que é relatada no Brasil e no mundo. A detecção de Plasmodium spp. no esfregaço sanguíneo é o método de rotina mas apresenta baixa sensibilidade quando comparado aos métodos moleculares. Considerando o impacto negativo da malária aviária nos pinguins, o objetivo deste estudo foi detectar a presença de Plasmodium spp. em pinguins-de-Magalhães usando a Reação em Cadeia da Polimerase (PCR), verificar as alterações clínicas, hematológicas e bioquímicas e o provável prognóstico em resposta à infecção. Amostras de sangue foram obtidas de 75 pinguins para determinar o hematócrito ( $\mathrm{Ht}$ ), contagens totais de eritrócitos e leucócitos, volume globular médio (VGM), concentração de ácido úrico, proteínas totais, albumina, globulinas e atividade da aspartato aminotransferase (AST). 0 sangue total foi usado para ensaios de PCR. A detecção de Plasmodium spp. foi obtida em 32,0\% dos indivíduos pela PCR e em 29,3\% pela análise microscópica. Anorexia, diarreia e alterações neurológicas foram mais frequentes nos pinguins com malária, e uma diferença significativa no peso entre pinguins infetados e não infectados foi detectada. Ht e VGM não mostraram diferença significativa. A contagem de eritrócitos e leucócitos foi menor nos animais com a malária aviária e leucopenia esteve presente em alguns pinguins. Contagens de basófilos e linfócitos foram mais baixas nos pinguins infectados, bem como elevadas contagens de monócitos estavam presentes. Não houve diferença significativa para a atividade da AST entre os animais infectados e não infectados. Houve um aumento significativo nos valores de ácido úrico, entretanto houve redução nos valores da albumina entre os pinguins infectados avaliados. Concluiu-se que Plasmodium spp. ocorre em pinguins-de-Magalhães de centros de reabilitação no sudeste brasileiro, comprometendo o peso dos animais infectados e com alterações clínicas aparecendo em casos graves da doença. Percebeu-se que embora alterações hematológicas possam não ser conclusivas, leucopenia, monocitose e diminuição de basófilos e linfócitos revelaram prognóstico desfavorável. A infecção por Plasmodium spp. pode cursar com aumento da concentração de ácido úrico e baixos valores de albumina.

TERMOS DE INDEXAÇÃO: Pinguim-de-Magalhães, Spheniscus magellanicus, reação em cadeia da polimerase, Plasmodium spp., bioquímica, prognóstico.

\section{INTRODUCTION}

Various studies have attempted to elucidate how hemoparasites may negatively affect the reproductive success of different species and make them more susceptible to predators and less able to establish territories (Feldman et al. 1995, Deviche et al. 2001).

The Magellanic penguin, Spheniscus magellanicus Foster, 1781 (Sphenisciformes: Spheniscidae), is a migratory marine bird of the South American continent which migrates from its breeding colonies to southern Brazil in search of food (Pütz et al., 2000, 2002, 2007,Cranfield 2003, Ruoppolo et al. 2004, Cubas et al. 2007, Mäder et al. 2010, Serafini et al. 2010). Along this route, some birds, especially the young ones, are exposed to adverse environmental conditions and occasionally get lost, reaching Southeastern and Northeastern Brazilian shores, where they are eventually seen stranded (García-Borboroglu et al. 2006, Cubas et al. 2007, Serafini et al. 2010).

Upon reaching these shores, the birds are fairly weak and often afflicted with diseases, such as avian malaria, a malady responsible for high mortality rates in captive penguins kept in uncovered areas (Griner 1974, Cranfield et al. 1991, Cubas et al. 2007). The disease is caused by blood protozoa (Plasmodium spp.) that affect various avian species and families, as well as reptiles, humans and other mammals (Thrall 2004, Belo 2007).

The signs vary from asymptomatic cases to death, which can be associated to higher parasitemia and immunosuppressive factors. The most frequent signs in penguins include anorexia, dyspnea, pale mucosa, regurgitation and sudden death (Fix et al. 1988, Atkinson et al. 2000, Cubas et al. 2007).

The detection of parasites in blood smears is still the routine diagnostic method, but may present a low sensitivity rate and is a cumbersome procedure (Perkins \& Schall 2002, Belo 2007). Molecular diagnostic methods such as Polymerase Chain Reaction (PCR) assays can increase sensitivity in identifying infections, although its cost is a limiting factor in rehabilitation centers.

Plasmodium spp. infections have been reported in at least ten different penguin species (Aptenodytes patagonicus, Eudyptes crestatus, E. chrysolophus, Eudyptula minor, Pygoscelis antarcticus, P. papua, Spheniscus demersus, S. humboldti, S. mendiculus and S. magellanicus) (Griner 1974, Fix et al. 1988, Brossy et al. 1999, Levin et al. 2009, Bueno et al. 2010, Dinhopl et al. 2011).

Graczyk et al. (1994), in search of Plasmodium spp. in 23 African penguins (Spheniscus demersu), noted that 5 animals $(21.7 \%)$ presented detectable parasitemia in their 
blood. As for the Magellanic penguins, a previous study with 25 specimens kept in rehabilitation centers in the city of Niteroi-RJ, detected a $24.0 \%$ prevalence of Plasmodium spp. (Pereira et al. 2009) in blood smears. Another study in Brazil reported the presence of malaria in Spheniscus magellanicus at the São Paulo zoo (Bueno et al. 2010).

However, there are few studies, especially in the state of Rio de Janeiro, on the diagnosis and laboratory findings of avian malaria in penguins. For instance, biochemistry tests have been largely used in domestic animals, but its use in wild birds still has unanswered gaps. According to Fleischman et al. (1968), Fix et al. (1988) and Graczyk et al. (1995), malarial exoerythrocytic schizonts inhabit the tissues of different internal organs, which allows us to assume that these schizonts might impair their functions and induce detectable variations in serum chemistry parameters.

Considering the significantly negative impact of avian malaria on this penguin species in various parts of the world and the lack of information on the prevalence of this disease, especially in the Brazilian Southeastern cost, as well as, on the hematologic and biochemical alterations caused by this malady, the aim of this study was to detect the presence of Plasmodium spp. in naturally infected Magellanic penguins using Polymerase Chain Reaction (PCR) assays along with clinical, hematologic, and biochemical examinations, as well as, to verify the likely prognosis of the infected animals.

\section{MATERIALS AND METHODS}

The development of this study has been approved by the Ethics Committee on Animal Research of the Universidade Federal Fluminense (n-215-10) and licensed (no 23927-1) for activities with scientific purpose by the Sistema de Autorização e Informação em Biodiversidade (SISBIO/IBAMA).

Study areas and blood sample collection. For this study 75 Magellanic penguins with or without clinical signs of avian malaria obtained from three institutions: Niterói Zoo, in Niterói city , Brazil ( $\left.22^{\circ} 53^{\prime} 00^{\prime \prime} \mathrm{S}, 43^{\circ} 06^{\prime} 13^{\prime \prime} \mathrm{W}\right)$, Universidade Estácio de Sá

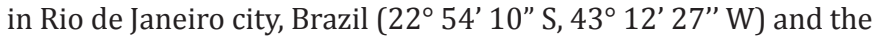
Santos Municipal Aquarium, in Santos city, Brazil (23 $57^{\prime} 39^{\prime \prime}$ S, $46^{\circ} 20^{\prime} 01^{\prime \prime} \mathrm{W}$ ) were studied between July and November 2010.

All of the Magellanic penguins Spheniscus magellanicus Foster 1781 (Sphenisciformes: Spheniscidae) present in these institutions were included in the study, regardless of age, sex and physical status.

Blood samples were collected from all animals by venipuncture and part of the whole blood was placed in ethylenediaminetetraacetic acid (EDTA) tubes and the remainder placed in anticoagulant-free tubes. Blood smears were done immediately after blood collection, fixed in methanol and stained with Giemsa (Merck ${ }^{\circledR}$, Rio de Janeiro, RJ, Brazil). During collection, the animals were submitted to individual physical exams and relevant findings were registered. All of the animals $(n=75)$ were submitted to onsite weighing during blood collection.

Hematologic and biochemical analysis. Using the blood in the EDTA tubes, microhematocrit tubes were filled and centrifuged to determine packed cell volume (PCV). Red blood cell (RBC) and white blood cell (WBC) counts were carried out in Neubauer counting chambers. Mean Corpuscular Volume (MCV) was calculated following the same method used for mammals. Differential WBC counts in blood films were performed based on the count of 100 WBC under 1000x magnification. Blood films were also used to verify infection by Plasmodium spp. within erythrocytes.
Serum was collected from the anticoagulant-free tubes and analyzed with spectrophotometry (BIO-200F, Bioplus ${ }^{\circledR}$, São Paulo, SP, Brazil) to determine uric acid, total protein, albumin and globulin levels, as well as, aspartate aminotransferase (AST) activity. For this, commercial kits (Labtest ${ }^{\circledR}$, Labtest Diagnóstica AS, Lagoa Santa, MG, Brazil) were used according to manufacturer recommendations.

Due to the rapid processing of samples, there was no hemolysis. Afterwards, the remaining whole blood was frozen at $-20^{\circ} \mathrm{C}$ for DNA extraction and PCR assays.

Reference values for healthy S. magellanicus used for comparison in this study were obtained from the International Species Information System-ISIS (www.isis.org).

DNA extraction and PCR amplification of Plasmodium spp. $\boldsymbol{c y t} \boldsymbol{b}$ fragment. DNA extraction from whole blood was performed using a commercial kit (illustra blood genomic Prep Mini Spin Kit - GE Healthcare ${ }^{\circledR}$, São Paulo, SP, Brazil), according to manufacturer recommendations, for nucleated red blood cells. The DNA obtained from these samples was submitted to amplification of a conserved region of the cytochrome b gene using nested-PCR, according to Perkins \& Schall (2002), with modifications.

The PCR reactions were carried out under the following conditions: an outer reaction using dNTPs $(0.2 \mathrm{mM})$, magnesium chloride- $\mathrm{MgCl}_{2}$ (3.0 mM), primers DW2 5'-TAA TGC CTA GAC GTA TTC CTG ATT ATC CAG-3' (10 pmol) and DW4 5'-TGT TTG CTT GGG AGC TGT AAT CAT AAT GTG-3' (10 pmol), Taq DNA polymerase (5 U/ $\mu \mathrm{L}$ ), a buffer and $3.0 \mu \mathrm{L}$ of genomic DNA. The reaction was subjected to 35 cycles at $94^{\circ} \mathrm{C}$ for $30 \mathrm{~s}, 50^{\circ} \mathrm{C}$ for $30 \mathrm{~s}$, and $72^{\circ} \mathrm{C}$ for $1.5 \mathrm{~min}$.

A $1.0 \mu \mathrm{L}$ aliquot of this product was used as a template for a nested reaction under the same conditions except using $1.5 \mathrm{mM}$ of $\mathrm{MgCl}_{2}$, and primers DW1 5'-TCA ACA ATG ACT TTA TTT GG-3' (10 pmol) and SABR 5'GCT-GTA-TCA-TAC-CCT-AAA-GG3' (10 pmol). The reaction was subjected to 40 cycles at $94^{\circ} \mathrm{C}$ for $30 \mathrm{~s}, 55^{\circ} \mathrm{C}$ for $30 \mathrm{~s}$, and $72^{\circ} \mathrm{C}$ for $1.5 \mathrm{~min}$ and then $72^{\circ} \mathrm{C}$ for $5 \mathrm{~min}$.

This last primer was obtained based on sequences available at the National Center for Biotechnology Information database (www.ncbi.nlm.nih.gov). The primer was also submitted to the Basic Local Alignment Search Tool (BLAST; www.ncbi.nlm.nih. gov/blast.cgi) and tested for the formation of primer dimers and its melting temperature (IDT, Integrated DNA Technologies; www. idtdna.com/analyzer). The conditions were optimized by setting an annealing temperature and $\mathrm{MgCl}_{2}$ concentration gradient. By using the new primer, it was possible to diminish the expected size of the products, facilitating its amplification.

Two samples of purified DNA of Plasmodium vivax confirmed by blood smears and extracted from naturally infected patients were used in each reaction as positive controls (about 676bp). These samples were provided by PhD Martha Cecilia Suárez Mutis (Instituto Oswaldo Cruz, Fundação Oswaldo Cruz, Rio de Janeiro, RJ, Brazil). Ultrapure water was added to each reaction as negative control.

The amplicons were subjected to electrophoresis in $1.5 \%$ agarose gel stained with ethidium bromide and observed under UV light.

Statistical analysis. Statistical analysis was performed using the Statistical Analysis System ("The SAS System", SAS Institute Inc., USA). The effect of infection or non-infection by Plasmodium spp. on the studied variables of the penguins in this study was evaluated using the chi-square test with a $5 \%$ significance.

\section{RESULTS}

\section{Prevalence of Plasmodium spp.}

All of the obtained blood samples $(\mathrm{n}=75)$ were submitted to PCR assays. Plasmodium spp. was detected in $32.0 \%$ 
Table 1. Mean \pm standard deviation for hematologic and biochemical variables of positive and negative Magellanic penguins (Spheniscus magellanicus) for Plasmodium spp. by Polymerase Chain Reaction

\begin{tabular}{lccc}
\hline Variable & $\begin{array}{c}\text { Negative } \\
\text { penguins }(\mathrm{n}=51)\end{array}$ & $\begin{array}{c}\text { Positive } \\
\text { penguins }(\mathrm{n}=24)\end{array}$ & $\begin{array}{c}\text { Reference } \\
\text { Values (ISIS) }\end{array}$ \\
\hline Red blood cell $\left(\mathrm{x} 10^{6} / \mu \mathrm{L}\right)$ & $1.29^{\mathrm{A}} \pm 0.338$ & $1.09^{\mathrm{B}} \pm 0.314$ & $1.6 \pm 0.53$ \\
Packed cell volume $(\%)$ & $37.18^{\mathrm{A}} \pm 8.24$ & $36.15^{\mathrm{A}} \pm 10.45$ & $41.4 \pm 9.2$ \\
Mean Corpuscular volume (fL) & $294.86^{\mathrm{A}} \pm 61.581$ & $336.43^{\mathrm{A}} \pm 69.141$ & $313.4 \pm 146.7$ \\
White Blood Cell $(/ \mu \mathrm{L})$ & $12,476^{\mathrm{A}} \pm 4,999.02$ & $10,003^{\mathrm{B}} \pm 3,979.70$ & $12,160 \pm 5,976$ \\
Basophils $(/ \mu \mathrm{L})$ & $81,08^{\mathrm{A}} \pm 116,05$ & $23,54^{\mathrm{B}} \pm 64,49$ & $207 \pm 126$ \\
Eosinophils $(/ \mu \mathrm{L})$ & $196,41^{\mathrm{A}} \pm 233,79$ & $230,04^{\mathrm{A}} \pm 263,79$ & $513 \pm 533$ \\
Heterophil $(/ \mu \mathrm{L})$ & $7,786.06^{\mathrm{A}} \pm 3,428.90$ & $6,501.38^{\mathrm{A}} \pm 2,870.06$ & $5,366 \pm 3,341$ \\
Lymphocyte $(/ \mu \mathrm{L})$ & $4,129.78^{\mathrm{A}} \pm 2,271.59$ & $2,827.77^{\mathrm{B}} \pm 1,409.84$ & $6,426 \pm 3,393$ \\
Monocyte $(/ \mu \mathrm{L})$ & $261.49^{\mathrm{A}} \pm 391.28$ & $335.92^{\mathrm{A}} \pm 273.35$ & $165 \pm 84$ \\
AST $(\mathrm{UI} / \mathrm{L})$ & $248.60^{\mathrm{A}} \pm 153.44$ & $302.64^{\mathrm{A}} \pm 174.45$ & $169 \pm 42$ \\
Uric acid $(\mathrm{mg} / \mathrm{dL})$ & $10.12^{\mathrm{B}} \pm 6.78$ & $16.88^{\mathrm{A}} \pm 7.30$ & $7.6 \pm 3.5$ \\
Total protein $(\mathrm{g} / \mathrm{dL})$ & $4.08^{\mathrm{A}} \pm 1.39$ & $3.48^{\mathrm{A}} \pm 1.74$ & $4.9 \pm 0.6$ \\
Albumin $(\mathrm{g} / \mathrm{dL})$ & $1.25^{\mathrm{A}} \pm 0.34$ & $1.03^{\mathrm{B}} \pm 0.41$ & $1.6 \pm 0.3$ \\
Globulin $(\mathrm{g} / \mathrm{dL})$ & $2.87^{\mathrm{A}} \pm 1.24$ & $2.45^{\mathrm{A}} \pm 1.53$ & $3.4 \pm 0.5$
\end{tabular}

Means followed by different letters (A or B) differed at a 5\% significance.

(24/75) of the Magellanic penguins in nested-PCR assays and in 29.3\% (22/75) in microscopic analyses.

\section{Hematological and biochemical results}

In the present study, infected and non-infected penguins had mean RBC and PCV values below normal ISIS ranges, but MCV within normal range in all animals (Table 1). PCV and MCV values showed no significant difference between infected and non-infected penguins. There was a significant difference $(\mathrm{p}<0.05)$ in RBC and in WBC counts, which were lower in animals with avian malaria (Table 1). There were no significant red cell morphologic alterations and hypochromic erythrocytes were not seen.

None of the animals showed leukocytosis. Yet, some infected penguins had leukopenia. Eosinophil averages were within ISIS reference values (Table 1) but high monocyte counts were found, although no significant difference was found between positive and negative animals. Basophil and lymphocyte counts were lower than the reference values in infected penguins. These values (basophils and lymphocytes) were also significantly lower $(\mathrm{p}<0.05)$ than values in non-infected penguins (Table 1). High counts of heterophils were observed in both groups.

AST activity was above normal range in $66.6 \%$ of infected penguins $(16 / 24)$, however, there was no significant difference between infected and non-infected animals (Table 1). There was a significant increase in uric acid levels and decrease in albumin levels in infected penguins (Table 1). However, high concentrations of uric acid, increased serum AST activity and low albumin levels were also found in penguins where Plasmodium spp. was not detected, which suggests that the penguins in the present study may have been affected by other inflammatory disorders and / or infectious diseases that contributed to the results. The serum protein and globulin levels were below ISIS reference values in some infected and non-infected birds but there were no significant differences between then.

\section{Clinical signs}

There were significant differences in weight averages among the analyzed penguins, where the average weight of
Table 2. Frequency of clinical signs observed in positive and negative Magellanic penguins (Spheniscus magellanicus) for Plasmodium spp. by Polymerase Chain Reaction

\begin{tabular}{lcc}
\hline Variable & \multicolumn{2}{c}{ Frequency (\%) } \\
\cline { 2 - 3 } & $\begin{array}{c}\text { Negative } \\
\text { penguins }(\mathrm{n}=51)\end{array}$ & $\begin{array}{c}\text { Positive } \\
\text { penguins }(\mathrm{n}=24)\end{array}$ \\
\hline Anorexia & $27.91 \% *$ & $69.57 \% *$ \\
Neurological alterations & $0.00 \% *$ & $17.39 \% *$ \\
Diarrhea & $13.64 \% *$ & $52.17 \% *$ \\
Dyspnea & $11.76 \%$ & $12.50 \%$ \\
Regurgitation & $0.00 \%$ & $4.17 \%$ \\
* Frequencies that differed at a $5 \%$ significance. &
\end{tabular}

animals infected with Plasmodium spp. (2.42kg \pm 0.83$)$ was significantly lower than the average weight of non-infected animals (3.02kg \pm 0.99 ).

The signs and symptoms observed during physical examination of each animal were dyspnea, anorexia, regurgitation, neurological disorders (which include tremors and incoordination) and greenish to blackish diarrhea. The frequency of anorexia, neurologic disorders and diarrhea was significantly $(\mathrm{p}<0.05)$ higher among malaria-positive animals (Table 2).

\section{DISCUSSION}

Differing from this study, Jones \& Shellam (1999) investigated blood smears of free and captive penguins of the Antartic region (Aptenodytes forsteri and Pygoscelis adeliae) and of temperate regions (Eudyptula minor and Spheniscus humboldti) but did not find a positive result for Plasmodium spp.

The presence of Plasmodium spp. in our study was higher than those found by other authors. Varghese (1987) found a $10.2 \%$ prevalence in 1977 and a $4.5 \%$ prevalence in 1984 when evaluating blood films of 16 different bird species of Papua New Guinea; Graczyk et al. (1994) found a $21.7 \%$ prevalence in blood films of African penguins $(S$. demersus) at the Baltimore Zoo, USA; Ribeiro et al. (2005) found Plasmodium spp. $16.5 \%$ of blood smears of 275 passerines captured in Minas Gerais state, Brazil; and Pereira 
et al. (2009) observed a $24.0 \%$ prevalence in blood smears of Magellanic penguins from the city of Niteroi, Brazil.

Using PCR, Ribeiro et al. (2005) reported a 39.6\% prevalence of avian malaria in passerine birds from Brazil; Levin et al. (2009) reported a 5.0\% prevalence of Plasmodium spp. infection in Galapagos penguins (S. mendiculus) and Bueno et al. (2010) detected P. relictum in S. magellanicus at the São Paulo Zoo, Brazil.

We believe that, when living in uncovered facilities, the animals are more exposed to avian malaria vectors and, therefore, a high incidence of infection was expected in this study, since most animals in this study were kept in uncovered areas and, according to Fleischman et al. (1968), Griner (1974) and Cubas et al. (2007) avian malaria is a serious problem in penguins kept in unprotected facilities.

The higher incidence obtained in this study can be explained by the geographical location of the state of Rio de Janeiro that has an essentially tropical climate and, as a result, is predisposed to a greater spread of vectors. We also cannot disregard the low sensitivity rate of morphological diagnoses when compared to the molecular detection method used in the present study.

It is reported that during the acute phase of malaria, birds can lose body mass (Al Dabagh et al. 1961, Massard \& Massard 1981, Massard 1982, Fix et al. 1988, Yorinks \& Atkinson 2000, Atkinson et al. 2001), justifying the average weight found in the animals infected with Plasmodium spp. $(2.42 \mathrm{~kg} \pm 0.83)$ that was lower than the average weight found in the non-infected animals $(3.02 \mathrm{~kg} \pm 0.99)$.

All signs observed during physical examinations of the studied penguins are frequently described in avian malaria reports (Atkinson et al. 2000, Cubas et al. 2007). Fix et al. (1988) and Cubas et al. (2007) characterized forceful food regurgitation as a clinical alteration in penguins with malaria. During this research, regurgitation was observed in one animal $(1 / 24,4.17 \%)$, which was infected by Plasmodium spp.

Weakness, neurological signs and greenish feces caused by severe cases of avian malaria have been described before (Al Dabagh et al. 1961, Massard \& Massard 1981, Massard 1982, Grim et al. 2003). In this study, aggravating signs of infection were also observed: $17.39 \%$ of parasitized animals presented neurological signs and $52.17 \%$ of the malaria-positive penguins presented greenish to blackish diarrhea.

It is described that infection by hemosporidians leads to anemia, however, laboratory abnormalities may be absent (Massard \& Massard 1981, Campbell \& Dein 1984, Atkinson et al. 2001, Thrall 2004, Valkiunas 2005, Mitchell \& Johns 2008). Bueno et al. (2010), in an investigation of $P$. relictum in Magellanic penguins, did not find any alterations in blood counts.

Mean values for RBC and PCV found in healthy S. $m a-$ gellanicus by Hawkey et al. (1989) (RBC $=1.99 \times 10^{6} / \mu \mathrm{L}$ \pm 0.42 ; PCV $=42 \% \pm 4.0$ ) were higher than the mean values found in the present study. Although the mean values of RBC and PCV were also below ISIS reference values (Table 1), there were no significant differences for PCV and alterations in RBC counts were not enough to alter MCV values.
Therefore, it was not possible to associate anemia with infection by Plasmodium spp. in these animals.

Leukocytosis is an alteration described in avian malaria (Almosny \& Santos 2001, Fowler \& Fowler 2001, Thrall 2004, Cubas et al. 2007, Mitchell \& Johns 2008), however, none of the infected animals showed this in the present study. Yet, some penguins had leukopenia. Leukopenia due to infectious and inflammatory processes can be considered an unfavorable prognosis by indicating that the production rate is below demand (Feldman et al. 2000, Cubas et al. 2007).

Infected birds presented high monocyte counts in this study. Monocytes are involved in inflammatory responses, phagocytic activity and migration into tissues to become macrophages (Harmon \& Glisson 1990), which could occur perhaps in response to avian malaria and could explain our monocytosis findings, though there are no reports so far linking monocytosis to inflammatory diseases in penguins.

The role of basophils and eosinophils in birds is still not fully understood and may be different from that of mammals (Cubas et al. 2007). Basophils contain heparin and the vasodilator histamine, which promotes blood flow to tissues. Therefore, they can induce eosinophil activity and assist in inflammatory processes. In the present study, the count of basophils was significantly $(p<0.05)$ lower in penguins with Plasmodium spp., reinforcing the idea of an unfavorable prognosis.

In broiler chicken and other birds, chronic stress and handling can lead to lymphoid tissue atrophy and reduce the number of circulating lymphocytes (Zulkifli\& Siegel 1995, Scope et al. 2002). Considering this, it is presumed that this was the cause of the significant reduction of lymphocytes in infected penguins in this study.

The AST activity is one of the most sensitive indicators of liver disease in birds but is not liver-specific (Fudge 2000, Thrall 2004, Schmidt et al. 2007). There were no significant differences between infected and non-infected penguins and, therefore, it was not possible to assert that Plasmodium spp. compromises liver function. The high AST activity values in $66.6 \%$ of animals with avian malaria suggests the presence of liver injury, but further tests are needed for confirmation (Vashist et al. 2011).

Uric acid is commonly used to evaluate renal function in birds (Fudge 2000, Thrall 2004). Graczyk et al. (1995) reported uric acid increases in captive African penguins $(S$. demersus) from the USA that were experimentally infected with $P$. relictum and, according to Fleischman et al. (1968), in African penguins, malaria can trigger extensive kidney damage, which is what possibly occurred to the Magellanic penguins in this study, leading to an increase in serum uric acid in the infected birds. However, in the study of Bueno et al. (2010), the investigated biochemistry results were mostly within normal range.

There was a significant decrease in albumin levels in infected penguins, what differs from the study of Graczyk et al. (1995) who did not observe any connection between protein, albumin and globulin levels or albumin/globulin ratios and African penguins infected with $P$. relictum. Albumin represents about $40-50 \%$ of serum proteins, it is syn- 
thesized by the liver and its measurement can complement the diagnosis of liver diseases (Thrall 2004, Schmidt et al. 2007). Thus, it is possible that albumin values have a greater importance in the diagnosis and prognosis of avian malaria in Magellanic penguins than what has been reported so far.

There was no significant difference in total protein and globulin levels between infected and non-infected penguins, and many penguins, regardless of infection, showed low serum protein levels. Considering that hypoproteinemia may also be observed in cases of food deprivation, liver disease or proteinuria in renal diseases (Lewandowski et al. 1986, Bowes et al. 1989, Ritchie et al. 1994, Thrall 2004, Schmidt et al. 2007), the low serum protein levels found in the studied specimens may be related to these causes rather than to infection.

Apparently, in some birds, such as chicken, this parasite seems to benefit from the host but without harming it (Anderson \& May 1979, Belo 2007). However, this is not observed in Magellanic penguins. The penguins that arrive at the Brazilian coast have a low resistance to Plasmodium spp. resulting in the large negative impact of this parasite on these young animals (Cubas et al. 2007). Further studies are important for a better understanding of the damage caused by avian malaria, including tests to identify liver injury, and to create a routine screening method in rehabilitation centers.

\section{CONCLUSIONS}

This study allowed us to conclude that Plasmodium spp. occurs in Southeastern Brazil which associated to the existence of vectors in the region, makes it an important risk factor for Magellanic penguins kept in rehabilitation centers of such region.

Avian malaria compromises the weight of infected Magellanic penguins with anorexia, neurological alterations and diarrhea appearing in severe cases of the disease in these birds. Hematologic abnormalities may not be conclusive, but leukopenia, monocytosis and significant decrease of basophils and lymphocytes revealed the presence of an inflammatory process associated with chronic stress and an unfavorable prognosis.

Plasmodium spp. infections may progress with elevated uric acid concentrations, and low albumin values. Increased AST activity was noted in infected penguins, however, high concentrations of uric acid, increased serum AST activity and low albumin values were also found in penguins in which Plasmodium spp. was not detected. This suggests that the penguins in the present study may have been affected by other inflammatory disorders and / or infectious diseases that contributed to the results.

We suggest that there is a lack of adaptation in the host-parasite relationship between Magellanic penguins and Plasmodium spp. justifying the high infection rate observed in this study, as well as the observed clinical, hematologic and biochemical alterations.

Acknowledgements.- To Santos Municipal Aquarium, Universidade Estácio de Sá and Zoológico de Niterói, for capturing and providing penguins for this study. To PhD Marta Cecília Suarez Mutis (Fundação Oswaldo Cruz, Rio de Janeiro-RJ, Brazil) for offering her positive control samples for the PCR.

\section{REFERENCES}

Al Dabagh M.A. 1961. Symptomatic partial paralysis in chicks with Plasmodium juxtanucleare. J. Comp. Pathol. 71:217-221.

Almosny N.R.P. \& Santos L.C. 2001. Laboratory support in wild animal medicine, p.500-505. In: Fowler M.E. \& Cubas Z.S. (Eds), Biology, Medicine and Surgery of South American Wild Animals. Iowa State University, Ames.

Anderson R.M. \& May R.M. 1979. Population biology of infectious diseases (Part I). Nature 280:361-367.

Atkinson C.T., Dusek R.J., Woods K.L. \& Iko W.M. 2000. Pathogenicity of avian malaria in experimentally infected Hawaii Amakihi. J. Wildl. Dis. 36(2):197-204.

Atkinson C.T., Dusek R.J. \& Lease J.K. 2001. Serological responses and immunity to superinfection with avian malaria in experimentally-infected Hawaii amakihi. J. Wildl. Dis. 37(1):20-27.

Belo N.O. 2007. Ocorrência de Plasmodium spp. em aves silvestres da família Psittacidae mantidas em cativeiro no Brasil. Dissertação de Mestrado em Medicina Veterinária Preventiva, Faculdade de Medicina Veterinária, Universidade Federal de Minas Gerais, Belo Horizonte, MG. 45p.

Bowes V., Julian R. \& Stirtzinger T. 1989. Comparison of Serum Biochemical Profiles of Male Broilers with Female Broilers and White Leghorn Chickens. Can. J. Vet. Res. 53:7-11.

Brossy J.J., Plös A.L., Blackbeard J.M. \& Kline A. 1999. Diseases acquired by captive penguins: what happens when they are released into the wild? Mar. Ornithol. 27(2):185-186.

Bueno M.G., Lopez R.P.G., Menezes R.M.T., Nascimento M.J.C., Lima G.F.M.C., Araújo R.A.S., Guida F.J.V. \& Kirchgatter K. 2010. Identification of Plasmodium relictum Causing Mortality in Penguins (Spheniscus magellanicus) from São Paulo Zoo, Brazil. Vet. Parasitol. 173:123-127.

Campbell T.W. \& Dein FJ. 1984. Avian Hematology; the basics. Vet. Clin. North Am., Small Anim. Pract. 14(2):223-248.

Cranfield M.R. 2003. Sphenisciformes (Penguins), p.103-110. In: Fowler M.E. \& Miller R.E. (Eds), Zoo and Wild Animal Medicine. $5^{\text {th }}$ ed, W.B. Saunders Company, Philadelphia.

Cranfield M.R., Beall F.B., Skjoldager M.T. \& Ialeggio D.M. 1991. Avian malaria. Spheniscus Penguin Newsletter 4:5-7.

Cubas Z.S., Silva J.C.R. \& Catão-Dias J.L. 2007. Tratado de Animais Selvagens. Roca, São Paulo. 1354p.

Deviche P., Greiner E.C. \& Manteca X. 2001. Seasonal and age-related changes in blood parasite prevalence in dark-eyed juncos (Junco hyemalis, Aves, Passeriformes). J. Exp. Zool, 289(1):456-466.

Dinhopl N., Mostegl M.M., Richter B., Nedorost N., Maderner A., Fragner K. \& Weissenböck H. 2011. Application of in-situ hybridization for the detection and identification of avian malaria parasites in paraffin wax-embedded tissues from captive penguins. Avian Pathol. 40(3):315-320.

Feldman B.F., Zinkl J.G. \& Jain N.C. 2000. Schalm's Veterinary Hematology. $5^{\text {th }}$ ed. Lippincott Williams and Wilkins, Philadelphia. 1344p.

Feldman R.A., Freed L.A. \& Cann R.L. 1995. A PCR test for avian malaria in Hawaiian birds. Mol. Ecol. 4(4):663-673.

Fix A.S., Waterhouse C., Greiner E.C. \& Stoskopf M.K. 1988. Plasmodium relictum as a cause of avian malaria in wild-caught Magellanic penguins (Spheniscus magellanicus). J. Wildl. Dis. 24(4):610-619.

Fleischman R.W., Sladen W.J.L. \& Melby E.C. 1968. Malaria (Plasmodium elongaturn) in captive African penguins (Spheniscus demersus). J. Am. Vet. Med. Assoc. 153:928-935.

Fowler G.S. \& Fowler M.E. 2001. Ordem Sphenisciformes, p.53-64. In: Fowler M. \& Cubas Z.S. (Eds), Biology, Medicine and Surgery of South Wild Animals. Iowa State University, Ames.

Fudge A.M. 2000. Laboratory Medicine: Avian and Exotic Pets. W.B. Saunders, Philadelphia. 486p.

García-Borboroglu P., Boersma P.D., Ruoppolo V., Reyes L., Rebstock G.A., 
Griot K., Heredia S.R., Adornes A.C. \& Silva R.P. 2006. Chronic oil pollution harms Magellanic penguins in the outhwest Atlantic. Mar. Pollut. Bull. 52:193-198.

Graczyk T.K., Cranfield M.R. \& Bicknese E.J. 1995. Evaluation of serum chemistry values associated with avian malaria infections in African black-footed penguins (Spheniscus demersus). Parasitol. Res. 81:316-319.

Graczyk T.K., Cranfield M.R., McCutchan M.F. \& Bicknese E.J. 1994. Characteristics of Naturally Acquired Avian Malaria Infections in Naive Juvenile African Black-footed Penguins (Spheniscus demersus). Parasitol. Res. 80(8):634-637.

Grim K.C., Merwe E.V.D., Sullivan M.B.A., Parson N., McCutchan T.F. \& Cranfield M. 2003. Plasmodium juxtanucleare associated with mortality in black-footed penguin (Spheniscus demersus) admitted to a rehabilitation center. J. Zoo Wildl. Med. 34:250-253.

Griner L.A. 1974. Avian malaria in penguins. Adv. Vet. Sci. Comp. Med. 18:251-271.

Harmon B.G. \& Glisson J.R. 1990. Disassociation of bactericidal and fungistatic activities from the oxidative burst of avian macrophages. Am. J. Vet. Res. 51(1):71-75.

Hawkey C.M., Horsley D.T. \& Keymer I.F. 1989. Haematology of wild penguins (Sphenisciformes) in the Falkland Islands. Avian Pathol. 18:495-502.

Jones H.I. \& Shellam G.R. 1999. The occurrence of blood-inhabiting protozoa in captive and free-living penguins. Polar Biol. 21(1):5-10.

Levin I.I., Outlaw D.C., Vargas F.H. \& Parker P.G. 2009. Plasmodium blood parasite found in endangered Galapagos penguins (Spheniscus mendiculus). Biol. Conserv. 142(12):3191-3195.

Lewandowski A.H., Campbell T.W. \& Harrison G.J. 1986. Clinical chemistries, p.192-200. In: Harrison G.J. \& Harrison L.R. (Eds), Clinical Avian Medicine and Surgery. W.B. Saunders Company, Philadelphia. 717p.

Mäder A., Sander M. \& Casa Jr G. 2010. Ciclo sazonal de mortalidade do pinguim de Magalhães, Spheniscus magellanicus influenciado por fatores antrópicos e climáticos na costa do Rio Grande do Sul, Brasil. Revta Bras. Ornitol. 18(3):228-233.

Massard C.L. \& Massard C.A. 1981. Aspectos Biológicos do Plasmodium (Novyella) juxtanucleare Versiani e Gomes, 1941 em aves no Brasil. Revta Bras. Med. Vet. 4(3):3-23.

Massard C.L. 1982. Caracterização do parasitismo por Plasmodium juxtanucleare (Haemosporidea: Plasmodiidae) em criação de Gallus gallus da raça Leghorn Branca. Arq. Univ. Fed. Rural Rio de J. 5:141-146.

Mitchell E.B. \& Johns J. 2008. Avian Hematology and Related Disorders. Vet. Clin. North Am., Exot. Anim. Pract. 11:501-522.

Pereira A.M., Campos S.D.E., Oliveira R.R.G.C., Soccio J.M.D., Velho P.B., Massard C.L. \& Almosny N.R.P. 2009. Frequência de infecção por Plasmodium sp. Em pingüins-de-magalhães (Spheniscus magellanicus Foster, 1781) encaminhados à Fundação Zoológico de Niterói. Anais XXI Congresso Brasileiro de Parasitologia e II Encontro de Parasitologia do Mercosul, Foz do Iguaçu, PR, p.642. (Abstract)

Perkins S.L. \& Schall J.J. 2002. A molecular phylogeny of malarial parasites recovered from cytochrome b gene sequences. J. Parasitol. 55:972-978.
Pütz K., Ingham R.J. \& Smith J.G. 2000. Satellite tracking of the winter migration of Magellanic penguins (Spheniscus magellanicus) breeding in the Falkland Islands. Ibis 142:614-622.

Pütz K., Ingham R.J. \& Smith J.G. 2002. Foraging movements of Magellanic penguins Spheniscus magellanicus during the breeding season in the Falkland Islands. Aquat. Conserv. Mar. Freshw. Ecosyst. 12(1):75-87.

Pütz K., Ingham R.J. \& Smith J.G. 2007. Winter migration of Magellanic penguins (Spheniscus magellanicus) from the southernmost distributional range. Mar. Biol. 152:1227-1235.

Ribeiro S.F., Sebaio F., Branquinho F.C.S., Marini M.A., Vago A.R. \& Braga E.M. 2005. Avian malaria in Brazilian passerine birds: parasitism detected by nested PCR using DNA from stained blood smears. Parasitol. 130(3):261-267.

Ritchie B.W., Harrison G.J. \& Harrison L.R. 1994. Avian Medicine: principles and application. Wingers Publishing Inc., Florida. 1384p.

Ruoppolo V., Adornes A.C., Nascimento A.C. \& Silva Filho R.P. 2004. Reabilitação de pinguins afetados por petróleo. Clín. Vet.51(9):78-83.

Schmidt E., Locatelli-Dittrich R., Santin E. \& Paulillo A. 2007. Patologia clínica em aves de produção, uma ferramenta para monitorar a sanidade avícola: uma revisão. Arch. Vet. Sci. 12(3):9-20.

Scope A., Filip T., Gabler C. \& Resch F. 2002. The Influence of stress from transport and handling on hematologic and clinical chemistry blood parameters of racing pigeons (Columba livia domestica). Avian Dis. 46(1):224-229.

Serafini P.P., Gomes A.L.M., Maranho A., Fernandes A., Mader A., Altiere B.L., Matias C.A.R., Niemeyer C., Kolesnikovas C.K.M., Guerra F., Dantas G.P.M., Vivekananda G., Nunes G.T., Oberg I., Simao Neto I., Fausto I.V., Araujo J., Catão-Dias J.L., Barros J.A., Cardoso L.G., Barbosa L.A., Duarte M.V., Barragana M., Labarthe N., Baldassin P., Maracini P., Vanstreels R.E.T., Velozo R.S., Silva-Filho R.P., Freitas R.R., Campos S.D.E., Serra S.D., Raso T.F., Muraoka T.R., Garcia T.F., Ruoppolo V. \& Carniel V.L. 2010. Projeto Nacional de Monitoramento de Pinguim-de-Magalhães (Spheniscus magellanicus). CEMAVE (ICMBio), Brasília. 36p.

Thrall M.A. 2004. Hematologia e Bioquímica Clínica Veterinária. Roca, São Paulo. 582p.

Valkiunas G. 2005. Avian Malaria Parasite and other Haemosporidia. CRC Press, Florida. 946p.

Varghese T. 1987. Endoparasites of birds of paradise in Papua New Guinea. Vet. Parasitol. 26(2):131-144.

Vashist U., Falqueto A.D., Lutrino D., Tunholi V.M., Tunholi-Alves V.M., Santos M.A.J., D’Agosto M., Massard C.L. \& Pinheiro J. 2011. Hepatic profile of Gallus gallus Linnaeus, 1958 experimentally infected by Plasmodium juxtanucleare Versiani \& Gomes, 1941. Vet. Parasitol. 1759(3/4):207211.

Yorinks N. \& Atkinson C.T. 2000. Effects of malaria (Plasmodium relictum) on activity budgets of experimentally infected juvenile Apapane (Himatione sanquinea). The Auk 117:731-738.

Zulkifli I. \& Siegel P.B. 1995. Is there a positive side to stress? Word's Poult. Journal 51:63-76. 